girdle, and some of the backbone; there are also indications of the young stages of the bony plates of the back.

During the past few months the Department of Entomology of the Museum has been searching along the south coast of England from Kent to the Isle of Wight for two moths, Hydraecia hucherardi and Lithophane lapidea. Apart from their rarity, the interest of these two species, which are inhabitants of central and southern Europe, is in the further evidence their occurrence in southern England provides of the gradual change of the climate of the British Isles, a change. which is already well supported by botanical evidence. Many specimens of $H$. hucherardi, the larva of which burrows in the roots of the marsh mallow, have been obtained, and the principal features of its life history have been ascertained; very few L. lapidea have so far been collected. Other recent work of the Museum includes a collecting trip to Yugoslavia by Mr. R. L. Coe, in order to obtain Diptera, more than nine thousand specimens being collected, during which contacts were made with the staffs of various scientific institutions. Another member of the staff, Mr. P. N. Lawrence, visited the south of France, where he collected more than four thousand specimens of Collembola in the neighbourhood of the Eastern Pyrenees. A very fine series of hydroid medusæ from Plymouth and elsewhere, numbering about fifteen hundred specimens, has been presented to the Museum by Mr. F. S. Russell, director of the Marine Biological Association of the United Kingdom, Plymouth, and a collection of approximately a thousand slides of foraminifera from various horizons from the Cretaceous to Recent has been presented by Miss M. A. Waller.

\section{The Ishihara Test and Defects in Colour Vision}

AN interesting article by Mr. Peter Cavanagh on "The Ishihara Test and Defects in Colour Vision" has been published in Occupational Psychology $(29,1 ; 1955)$. The investigation was originally undertaken for the guidance of psychologists working in the Industrial Rehabilitation Units of the Ministry of Labour and National Service during the Second World War, and the Ministry has suggested that it should be given wider circulation. It is true that many people with defective colour vision are unaware of their condition, since they see all the things that other people see and they know what colours these things are said to have. This may be fairly adequate for ordinary life; but in certain critical situations they can run into difficulties and even danger, so that it is important that people should be tested for the accuracy of their colour vision. As with all tests concerning human beings, infallibility cannot be claimed; but, used with adequate controls, the test has proved to be of great value. Mr. Cavanagh discusses the incidence and types of defective colour vision, its congenital nature, as well as its occupational implications, with a detailed study of the test, its limitations and value and the technique for reducing error.

\section{Council for the Preservation of Rural England : Report for 1954-55}

The twenty-ninth annual report, for 1954-55, of the Council for the Preservation of Rural England (pp. 30 ; London, 1955) is again a fully documented account of the action taken during the year to safeguard the amenities of rural England. On town and country planning, the Council welcomed the statement of the Minister of Housing and Local Government expressing determination to stop further unrestricted sprawl of the great cities, but regrets the fact that, apart from London, no other great city has defined a formal 'Green Belt' around it. Among other matters to which the Council has given its attention are the control of unsightly advertisements, the location of a number of mineral-working sites, the position of television stations and the distribution of electricity undertakings, the conservation of Nature, the landscape treatment of roads and bridges, pollution of the air, sea and rivers, and the preservation of buildings. In a separate report published by the Sheffield and Peak District Branch of the Council (pp. 30; Sheffield, 1955), an account is given of the vigorous opposition being made to the proposed road-racing circuit in the Peak National Park. Such a circuit was approved in principle by Derbyshire County Council on May 4 without consulting the Peak Park Planning Board; this onesided action is possible because highway authorities are not subject to planning control.

\section{Association of Applied Biologists : Jubilee Volume}

Is September last year the Association of Applied Biologists celebrated its fiftieth anniversary by a five-day session in which many distinguished biologists took part and many interesting papers were communicated. The proceedings of the jubilee meeting have now been published as Vol. 42 of the Annals of Applied Biology (pp. $414+8$ plates. Cambridge : University Press, 1955; 25s. net). In all, some thirty-nine speeches and papers are recorded. Some of these deal with general topics such as the changing problems of applied biology, contributed by Sir John Russell, progress in plant pathology by E. C. Stakman, and the contribution of pure science to applied biology by V. B. Wigglesworth. The others relate to a variety of special topics, including the pests of crop plants and of stored products, nematodes, virus and other diseases, the use of growth-regulating substances, education and extension services, crop protection, and the forecasting and assessment of plant diseases. Detailed references to individual papers cannot be made here, but the jubilee volume may unreservedly be recommended to readers in this field as one of exceptional interest and importance.

\section{Sheffield Interchange Organization : Work during 1954-55}

AT the twenty-second annual general meeting of the Sheffield Interchange Organization, held at the Central Library, Sheffield, another firm was admitted to the Organization, bringing the total membership to forty-one, including the University, the City Library, and industrial and government research institutions. 2,649 books, periodicals and other scientific and technical papers were exchanged during 1954-55. Among the matters under consideration were the difficulties experienced by members in obtaining United States government research reports within a reasonable time, and problems encountered in tracing and consulting university dissertations which might be of interest to industrial research workers. The City Librarian was asked to approach the appropriate authorities regarding the quicker supply of American reports, and he reported correspondence with the Standing Conference of National 